\title{
Forum
}

\section{AIDS Research Not Restricted to the United States}

I have just read Sherrill et al., "What Political Science Is Missing by Not Studying Aids," and while I agree with the basic argument I am disappointed at its lack both of generosity and of awareness of what is happening outside the United States. While my book AIDS in the Mind of America is cited, it might have deserved some discussion as by far the earliest work by a political scientist to discuss the epidemic, particularly as the authors do discuss a far less substantial paper of mine written two years later. Moreover that book quite explicitly spoke of the "construction" of AIDS-and (which should gratify your authors) in explicit Foucauldian terms (see p. 51).

Had the authors looked outside the United States they would have found a greater number of political scientists working in the field (see, e.g., the series of books produced by Falmer Press from the annual social aspects of AIDS conferences in London). I agree that much of the best work on the political theories and implications of HIV is coming from community activists, but such activism is not restricted to the United States-nor is interesting research. That the article cites no sources from outside North America-while talking of the need for global analyses of the impact of the epidemic-suggests that even those who are making the case for more attention to HIV/ AIDS in political science need to look beyond their own immediate horizons.

Dennis Altman LaTrobe University (Australia)

\section{More Reflections on the Retired Professor}

Albert Somit's reflections on the retired professor ("From Professor of Political Science to Professor Emeritus," PS, December 1992) is, I suspect, of little interest to anybody under 60 years of age. It is of great interest, however, to those who have retired or will soon retire, and it should be of great interest to university administrators and the faculty in general. His theme was that universities ought to develop policies that embrace in specific ways emeriti who continue to pursue relevant research and publication.

My own experience may emphasize the arguments he made. I retired on January 1, 1989 but continued research and writing and participated in conferences near by, by paying my own way. In fact, I got more done in three years than in any eight years of teaching, research, committees, theses supervision, faculty senate service, directing a program, and serving as graduate advisor.

In 1992, I was invited to an international conference in Montreal to present a paper on some theoretical work I was doing. The early phases of the research had been financially supported by my university's Division of Research and Sponsored Programs before I had retired. I assumed (correctly, I was told by a high administrator) that even though I was retired, I should be able to receive some travel support to present a paper reporting the results of original research. I filled out the appropriate forms and gave them to the department chair who approved them and forwarded them to the offices of the faculty union-the AAUP. There the request was denied on the grounds that I was "not a bargaining unit member." My years of membership before retirement were of no concern to the union. Emeritus status simply cuts one off precipitously from university benefits apart from library privileges and discounts at the campus book store, and in my case a joint office with other retirees supplied willingly by my department. Because I wanted feedback from people working in my area of study, I personally paid over $\$ 600$ to attend the conference.

Dr. Somit noted that as universities suddenly sever all ties that involve any real obligations to the once highly valued professor they tempt other professors who might otherwise retire to hang on rather than "become members of a manifestly less privileged caste." $\mathrm{He}$ asserted, rightly I believe, that "if even a small percentage of faculty choose to stay on, our schools will face a situation to which they have manifestly given little thought."

It would seem wise of university administrators, therefore, to begin to think about what retirement means both to the individual and the university, and especially about the value of retirees who continue to be productive researchers and scholars. Dr. Somit's reflections provide a good beginning.

Claude S. Phillips

Professor Emeritus of Political

Science

Western Michigan University

\section{Nevada Court Supports Fett and Ponder Conclusion}

Although Patrick J. Fett and Daniel E. Ponder were probably unaware when writing "Congressional 
Term Limits, State Legislative Term Limits and Congressional Turnover: A Theory of Change" (PS, June 1993), the Nevada Supreme Court has provided singular veracity to their conclusion that "state-imposed congressional limits will not survive" constitutional scrutiny by the courts.

In September 1992, that court held in Stumpf v. Lau (839 P.2d 120) that a ballot question limiting congressional terms in office could not be placed on the November 1992 ballot. Basing its decision on Powell $v$. McCormack in which the U.S. Supreme Court held that neither the state nor Congress possessed the "power to alter qualifications for these federal constitutional officers, "the state supreme court concluded that such a provision, if passed, would "palpably violate the paramount law and would inevitably be futile and nugatory and incapable of being made operative under any conditions or circumstances." Therefore, the court exercised its power to enjoin the question's submission to the voters on the basis that there was "no political utility in burdening an already strapped public fisc with the expense that would inevitably be incurred placing a meaningless question on the ballot, conducting the election, and tallying the votes."

For those who are interested in the legal ramifications of state-imposed limits on congressional terms, 1 would urge them to examine my article, "Federal Term Limits and the Nevada Supreme Court," in Volume 3, Number 3 (Spring 1992) of State Constitutional Commentaries and Notes, published by the Edward McNall Burns Center for State Constitutional Studies at Rutgers.

Michael W. Bowers

University of Nevada, Las Vegas

\section{Moving? . . . . . Don't Forget to Notify APSA}

To ensure that all your subscriptions, membership information, and mailings reach you, return this form to APSA at least one month before you move.

Name:

Primary

Address:

Date new address effective:
Membership Number: Secondary
Address (optional):

Please send all APSA correspondence to my primary address.

Please send the following checked correspondence to my secondary address, all other correspondence should be sent to my primary address.
Directory
Journals
Meeting Information
Renewals/General Information
Personnel Service Newsletter

Please return to: Membership Office

American Political Science Association

1527 New Hampshire Avenue, NW

Washington, DC 20036 